\title{
Allocation of the S-genome chromosomes of Aegilops variabilis Eig. carrying powdery mildew resistance in triticale (× Triticosecale Wittmack)
}

\author{
M. Kwiatek ${ }^{1} \cdot$ J. Belter $^{1} \cdot$ M. Majka ${ }^{1} \cdot$ H. Wiśniewska ${ }^{1}$
}

Received: 23 February 2015 / Accepted: 25 March 2015 /Published online: 14 April 2015

(C) The Author(s) 2015. This article is published with open access at Springerlink.com

\begin{abstract}
It has been hypothesized that the powdery mildew adult plant resistance (APR) controlled by the Pm13 gene in Aegilops longissima Schweinf. \& Muschl. $\left(\mathrm{S}^{1} \mathrm{~S}^{1}\right)$ has been evolutionary transferred to Aegilops variabilis Eig. (UUSS). The molecular marker analysis and the visual evaluation of powdery mildew symptoms in Ae. variabilis and the $A e$. variabilis $\times$ Secale cereale amphiploid forms $(2 n=6 x=42$, UUSSRR) showed the presence of product that corresponded to Pm13 marker and the lower infection level compared to susceptible model, respectively. This study also describes the transfer of Ae. variabilis Eig. $\left(2 n=4 x=28, \mathrm{U}^{\mathrm{v}} \mathrm{U}^{\mathrm{v}} \mathrm{S}^{\mathrm{v}} \mathrm{S}^{\mathrm{v}}\right)$ chromosomes, carrying powdery mildew resistance, into triticale ( $\times$ Triticosecale Wittm., $2 n=6 x=42$, AABBRR) using Ae. variabilis $\times S$. cereale amphiploid forms. The individual chromosomes of Ae. variabilis, triticale 'Lamberto' and hybrids were characterized by genomic and fluorescence in situ hybridization (GISH/FISH). The chromosome configurations of obtained hybrid forms were studied at first metaphase of
\end{abstract}

Handling Editor: Heiti Paves

Key message We have demonstrated the $P m 13$ resistance gene originally found on chromosome $3 \mathrm{~S}^{1}$ of Ae. longissima has been transferred to Ae. variabilis. We have obtained 26 triticale plants carrying $3 \mathrm{~S}^{\mathrm{v}}$ chromosome(s) with the powdery mildew resistance.

M. Kwiatek

mkwi@igr.poznan.pl

J. Belter

jbel@igr.poznan.pl

M. Majka

mmaj@igr.poznan.pl

H. Wiśniewska

hwis@igr.poznan.pl

1 Institute of Plant Genetics, Polish Academy of Sciences, Strzeszyńska 34, 60-479 Poznań, Poland meiosis of pollen mother cells (PMCs) using GISH. The statistical analysis showed that the way of S-genome chromosome pairing and transmission to subsequent hybrid generations was diploid-like and had no influence on chromosome pairing of triticale chromosomes. The cytogenetic study of hybrid forms were supported by the marker-assisted selection using Pm13 marker and visual evaluation of natural infection by Blumeria graminis, that allowed to select the addition or substitution lines of hybrids carrying chromosome $3 \mathrm{~S}^{\mathrm{v}}$ which were tolerant to the powdery mildew infection.

Keywords Aegilops $\cdot$ Chromosome transfer · In situ hybridization $\cdot$ Molecular marker $\cdot$ Powdery mildew . Resistance genes $\cdot$ Triticale

\section{Introduction}

Powdery mildew caused by Blumeria graminis (DC.) E.O. Speer f. sp. Tritici Em. Marchal $($ Bgt $)=$ Erysiphe graminis DC. Ex Merat f. sp. Tritici Em. Marchal is one of the widespread fungal diseases in cereals. This pathogen has recently infected triticale ( $\times$ Triticosecale Wittm.), man-made, artificial cereal, which was created to combine the characteristics of cold, disease tolerance and adaptation to unfavourable soils and climates with the productivity and nutritional qualities (Woś et al. 2002). At the beginning of the triticale production, the diseases did not appear to be a serious limitation, probably because of lack of the appropriate, triticale-directed pathotypes of fungal pathogens. Moreover, the grown areas of this crop were incidental to cause serious shifts in the pathogen virulence (Ammar et al. 2004). While the harvest area of triticale began to increase, the new hybrid pathotypes carrying virulence genes appeared (Arseniuk 1996). The new, resistant cultivars could eliminate the fungicides accumulation in grain 
and reduce the crop losses caused by powdery mildew. Two types of resistance to powdery mildew have been identified so far (Flor 1971). First is called monogenic (vertical) or racspecific resistance, which is effective for some isolates of the pathogen, but ineffective for others. Race-specific resistance is expressed in seedlings and involve single major R genes, in a gene-for-gene interaction (Chen and Chełkowski 1999). Race-specific resistance genes are widely used to combat the wheat diseases, yet the resistance is often short-lived, especially when the genes are employed singly in new varieties (Marais et al. 2008). Second type of resistance to powdery mildew is known as an adult plant resistance (APR), also called 'slow mildewing' and 'partial resistance,' which decelerates the infection, growth and reproduction of the pathogen in adult plants. APR to powdery mildew is more durable than race-specific resistance; therefore it is more desirable in breeding programmes. One of the APR genes is $P m l 3$ powdery mildew resistance gene that ensures high tolerance to all known races of this disease in wheat. The $P m 13$ gene has been transferred from the chromosome $3 \mathrm{~S}^{1}$ of Aegilops longissima Schweinf. \& Muschl. $\left(2 n=2 x=14\right.$ chromosomes; $\left.S^{l} S^{1}\right)$ into common wheat, Triticum aestivum L. cv. 'Chinese Spring' (Ceoloni et al. 1988). Considering the synteny in the genome construction of related species, which evolved from a common ancestral gene by speciation, Cenci et al. (2003) hypothesized that the Pm13 marker linked with powdery resistant gene has a conservative character. On this basis, it can be assumed that species with S-genome chromatin such as tetraploids (Aegilops variabilis Eig.) and hexaploids (Aegilops vavilovi Zhuk.) could carry the genomic region responsible for powdery mildew resistance. What is more, Ae. longissima is considered as a donor of S-genome (Yu and Jahier 1992; Zhang et al. 1992; Badaeva et al. 1998) of Ae. variabilis $\left(\mathrm{U}^{\mathrm{v}} \mathrm{U}^{\mathrm{v}} \mathrm{S}^{\mathrm{v}} \mathrm{S}^{\mathrm{v}}\right)$. Ae. variabilis has been used as a donor of desirable genes to wheat through interspecific hybridization such as powdery mildew resistance (Spetsov et al. 1997), leaf rust resistance (Marais et al. 2008) and resistance to nematodes (Coriton et al. 2009).

The aims of this study were to: (1) evaluate the presence and the expression of Pml3 gene in Ae. variabilis; (2) to identify the individual chromosomes of Ae. variabilis responsible for powdery mildew resistance and (3) transfer them into triticale.

The distant crossing between diploid Aegilops species and hexaploid triticale can be disturbed because of (1) different ploidy level of the parental components and (2) the expression of $P h 1$ gene located on chromosome 5B in wheat (or triticale), responsible for homologues chromosome pairing during meiosis (Riley and Chapman 1958; Lukaszewski and Kopecký 2010). To avoid the unwanted crossing limitations connected with different chromosome number in parental forms and to circumvent the chromosome pairing system controlled by $P h 1$ gene, we assumed that using amphiploid forms of $A e$. variabilis $\times$ Secale cereale $\left(\mathrm{U}^{\mathrm{v}} \mathrm{U}^{\mathrm{v}} \mathrm{S}^{\mathrm{v}} \mathrm{S}^{\mathrm{v}} \mathrm{RR}\right)$ in the crosses with triticale (AABBRR) will have a significant impact on $\mathrm{F}_{1}$ hybrid stability because of R-genome chromosomes, which will be able to pair during prophase I of meiosis and will ensure the functional daughter cells formation and sufficient level of vital pollen grains as a consequence.

In this purpose, four subsequent generations $\left(\mathrm{F}_{1}\right.$ to $\left.\mathrm{BC}_{2} \mathrm{~F}_{2}\right)$ of $($ Ae. variabilis $\times S$. cereale $) \times$ triticale hybrids were obtained. The chromosome composition during metaphase of mitosis in root apical meristems and chromosome pairing during metaphase I (MI) of meiosis of the pollen mother cells (PMCs) were characterized using fluorescence and genomic in situ hybridization (FISH/GISH). Finally, the Pm13 marker (Cenci et al. 1998) was verified in the Ae. variabilis, parental components and in the hybrid plants and compared with visual evaluation of powdery mildew infection.

\section{Materials and methods}

\section{Plant material}

Glasshouse experiments were carried out in four subsequent vegetation seasons at Institute of Plant Genetics, Polish Academy of Sciences in Poznań, Poland. Seeds of Aegilops umbellulata Zhuk. (PI 222762; $2 n=2 x=14 ; \mathrm{U}^{\mathrm{u}} \mathrm{U}^{\mathrm{u}}$ ) and $A e$. longissima (PI 604112; $2 n=2 x=14 ; \mathrm{S}^{1} \mathrm{~S}^{1}$ ) were kindly supplied for the study from the National Small Grains Germplasm Research Facility, National Small Grains Collection (Aberdeen, Idaho, USA). Seeds of Ae. variabilis were received from the collection of Professor M. Feldman (The Weizmann Institute of Science, Israel). The Ae. variabilis $\times S$. cereale amphiploids $\left(\mathrm{U}^{\mathrm{V}} \mathrm{U}^{\mathrm{V}} \mathrm{S}^{\mathrm{V}} \mathrm{S}^{\mathrm{V}} \mathrm{RR}, 2 n=6 x=42\right)$ were obtained by Wojciechowska and Pudelska (1999). The $F_{1}$ $($ Ae. variabilis $\times$ S. cereale $) \times$ triticale hybrids were obtained by crossing of triticale cv. 'Lamberto' with Ae. variabilis $\times$ $S$. cereale amphiploids as a pollinator. Backcrosses with the triticale as a male parent were used to achieve following generations $\left(\mathrm{BC}_{1} \mathrm{~F}_{1}\right.$ and $\left.\mathrm{BC}_{2} \mathrm{~F}_{1}\right)$. Finally, the self-pollinations of $\mathrm{BC}_{2} \mathrm{~F}_{1}$ hybrids were made to gain $\mathrm{BC}_{2} \mathrm{~F}_{2}$ plants. The percentage ratio of the total amount of seeds from each plant with the total amount of pollinated flowers of each plant was calculated (Table 1).

\section{Chromosome preparation}

Seeds were germinated on moist filter paper in Petri dishes for 3-4 days. For mitosis metaphase accumulation, the root-tips were collected and stored in ice for $26 \mathrm{~h}$. Afterwards, the plants were placed in the vernalisation chamber for 6 weeks and then located in the glasshouse until harvest. The fixation of the root-tips was made using ethanol and acetic acid (3:1, $v / v)$. The chromosome preparations were made according to 
Table 1 Results of distant crossing between hexaploid $(2 n=6 \mathrm{x}=42)$ forms of triticale 'Lamberto' with Ae. variabilis $\times$ S. cereale amphiploid and its progeny

\begin{tabular}{|c|c|c|c|c|c|c|}
\hline \multirow[t]{2}{*}{ Hybrid generation } & \multicolumn{2}{|c|}{ Cross combination } & \multirow{2}{*}{$\begin{array}{l}\text { Number of } \\
\text { pollinated flowers }\end{array}$} & \multirow{2}{*}{$\begin{array}{l}\text { Number of } \\
\text { seeds obtained }\end{array}$} & \multirow[t]{2}{*}{ Crossability } & \multirow{2}{*}{$\begin{array}{l}\text { Number of adult } \\
\text { plants with } P m 13 \text { marker }\end{array}$} \\
\hline & Female parent & Male parent & & & & \\
\hline $\mathrm{F}_{1}$ & triticale $(6 x)$ & Ae. variabilis $\times S$. cereale $(6 x)$ & 106 & 19 & 0.18 & 6 \\
\hline $\mathrm{BC}_{1} \mathrm{~F}_{1}$ & $\mathrm{~F}_{1}$ & Triticale $(6 x)$ & 68 & 17 & 0.25 & 5 \\
\hline \multirow[t]{5}{*}{$\mathrm{BC}_{2} \mathrm{~F}_{1}$} & 1 & Triticale $(6 x)$ & 46 & 3 & 0.07 & 0 \\
\hline & 3 & Triticale $(6 x)$ & 116 & 6 & 0.05 & 0 \\
\hline & 4 & Triticale $(6 x)$ & 82 & 11 & 0.13 & 11 \\
\hline & 6 & Triticale $(6 x)$ & 30 & 2 & 0.03 & 1 \\
\hline & 7 & Triticale $(6 x)$ & 56 & 3 & 0.05 & 3 \\
\hline \multirow[t]{15}{*}{$\mathrm{BC}_{2} \mathrm{~F}_{2}$} & $4 / 1$ & Self & 64 & 0 & 0 & 0 \\
\hline & $4 / 2$ & Self & 44 & 0 & 0 & 0 \\
\hline & $4 / 3$ & Self & 52 & 0 & 0 & 0 \\
\hline & $4 / 4$ & Self & 48 & 0 & 0 & 0 \\
\hline & $4 / 5$ & Self & 74 & 27 & 0.36 & 2 \\
\hline & $4 / 6$ & Self & 64 & 3 & 0.05 & 3 \\
\hline & $4 / 7$ & Self & 60 & 0 & 0 & 0 \\
\hline & $4 / 8$ & Self & 40 & 0 & 0 & 0 \\
\hline & $4 / 9$ & Self & 52 & 0 & 0 & 0 \\
\hline & $4 / 10$ & Self & 73 & 10 & 0.13 & 10 \\
\hline & $4 / 11$ & Self & 66 & 10 & 0.15 & 10 \\
\hline & $6 / 1$ & Self & 68 & 0 & 0 & 0 \\
\hline & $7 / 1$ & Self & 48 & 0 & 0 & 0 \\
\hline & $7 / 2$ & Self & 17 & 0 & 0 & 0 \\
\hline & $7 / 3$ & Self & 52 & 0 & 0 & 0 \\
\hline
\end{tabular}

Hasterok et al. (2006). The $\mathrm{F}_{1}$ to $\mathrm{BC}_{2} \mathrm{~F}_{2}$ hybrids were grown in the nursery and their meiotic behaviour was analysed in PMCs at MI of meiosis. Anthers of the hybrids containing PMCs at MI were fixed in 1:3 $(v / v)$ acetic acid/ethanol and stored at $-20{ }^{\circ} \mathrm{C}$ for a maximum of 2 months. MI of meiosis preparations were made according to Zwierzykowski et al. (2008). The anthers were squashed in $45 \%$ acetic acid, and the slides were stored at $4{ }^{\circ} \mathrm{C}$ until in situ hybridization.

\section{Probe labelling}

Total genomic DNA was extracted from fresh leaves of $A e$. umbellulata (UU), Ae. longissima $\left(\mathrm{S}^{1} \mathrm{~S}^{1}\right)$ and triticale 'Lamberto' (AABBRR) using GeneMATRIX Plant \& Funghi DNA Purification Kit (EURx Ltd.). Genomic DNA from Ae. umbellulata and Ae. longissima was labelled by nick translation (using NickTranslation Kit, Roche, Mannheim, Germany) with digoxigenin-11-dUTP (Roche) or tetramethyl-5-dUTP-rhodamine (Roche), respectively. Blocking DNA from triticale was sheared to fragments of 5$10 \mathrm{~kb}$ by boiling for 30-45 min and used at a ratio of 1:50 (probe:block). The 5S rDNA probe was amplified from the wheat clone pTa794 (Gerlach and Dyer 1980) by polymerase chain reaction (PCR) with tetramethyl-rhodamine-5-dUTP (Roche) using universal M13 'forward' (5'-CAG GGT TTT CCC AGT CAC GA-3') and 'reverse' (5'-CGG ATA ACA ATT TCA CAC AGG A-3') sequencing primers. The thermal cycling programme consist of the following: $94{ }^{\circ} \mathrm{C}$ for $1 \mathrm{~min}$, 39 cycles of $94^{\circ} \mathrm{C}$ for $40 \mathrm{~s}, 55^{\circ} \mathrm{C}$ for $40 \mathrm{~s}$, and $72{ }^{\circ} \mathrm{C}$ for $90 \mathrm{~s}$, and $72^{\circ} \mathrm{C}$ for $5 \mathrm{~min}$. The $25 \mathrm{~S}$ rDNA probe was made by nick translation of a 2.3-kb ClaI sub-clone of the 25-5.8-18S rDNA coding region of Arabidopsis thaliana (Unfried and Gruendler 1990) with digoxigenin-11-dUTP (Roche). It was used for detection of 25-5.8-18S rDNA loci. The pSc119.2 repetitive DNA sequence, kindly supplied from Dr Kubalaková (Laboratory of Molecular Cytogenetics and Cytometry, Institute of Experimental Botany, Olomouc, Czech Republic), was amplified and labelled by PCR with digoxigenin-11-dUTP (Roche) by using universal M13 primers (Vrána et al. 2000). The probe pAs1 (Afa family) was amplified by PCR from the genomic DNA of Ae. tauschii and labelled with digoxigenin-11-dUTP (Roche) according to Nagaki et al. (1995). Digoxigenin detection was made using anti-digoxigenin-fluorescein antibody (Roche). 


\section{In situ hybridization}

FISH was carried out to study the mitotic chromosomes of root meristems. On the other hand, GISH was used to examine both the mitotic chromosomes of root meristemes and meiotic chromosomes of PMCs. Four probes were subjected to in situ hybridization on the same chromosome preparations. First FISH was made according to Książczyk et al. (2011) with minor modifications of Kwiatek et al. (2013), using 25S (used for detection of 25-5.8-18S rDNA loci) and 5S rDNA (pTa794). The hybridization mixture (40 $\mu$ l per slide) contained $90 \mathrm{ng}$ of each probe in the presence of salmon sperm DNA, $50 \%$ formamide, $2 \times \mathrm{SSC}, 10 \%$ dextran sulphate, and was denatured at $75^{\circ} \mathrm{C}$ for $10 \mathrm{~min}$ and stored on ice for $10 \mathrm{~min}$. Chromosomal DNA was denatured in the presence of the hybridization mixture at $75^{\circ} \mathrm{C}$ for $5 \mathrm{~min}$ and allowed to hybridize overnight at $37^{\circ} \mathrm{C}$. For detection of the hybridization signals, anti-digoxigenin conjugated with FITC (Roche) was used. After documentation of the FISH sites, the slides were washed according to Heslop-Harrison (2000) $(2 \times$ $45 \mathrm{~min}$ in $4 \times \mathrm{SSC}$ Tween, $2 \times 5 \mathrm{~min}$ in $2 \times \mathrm{SSC}$, at room temperature).

Second FISH with pSc119.2 and pAs1 (labelled with digoxygenin-11-dUTP and tetramethyl-rhodamine-5-dUTP, respectively) was made with the same conditions after reprobing. After second reprobing, GISH was carried out according to Kwiatek et al. (2012) with modifications. Multicolour GISH was carried out using U-genome probe (from Ae. umbellulata), $\mathrm{S}^{1}$-genome probe (from Ae. longissima) and unlabelled triticale genomic DNA which was used as specific blocker. The GISH mixture $(40 \mu \mathrm{L}$ per slide), containing $50 \%$ formamide, $2 \times \mathrm{SSC}, 10 \%$ dextran sulphate, $90 \mathrm{ng}$ each of the genome probes, and $4.5 \mu \mathrm{g}$ blocking DNA, was denatured at $75^{\circ} \mathrm{C}$ for $10 \mathrm{~min}$ and stored on ice for $10 \mathrm{~min}$. In case of initial GISH on triticale 'Lamberto' chromosomes, the hybridization mix contained the following: A-genome probe generated from genomic DNA of Triticum monococcum L., R-genome probe (rye, S. cereale L.) and blocking DNA from B-genome (Aegilops speltoides Tausch; $2 n=2 x=14$; SS). The chromosomal DNA denaturation, hybridization and immunodetection conditions were the same as above-mentioned. Mitotic and meiotic (MI) cells were examined with an Olympus XM10 CCD camera attached to an Olympus BX 61 automatic epifluorescence microscope. Image processing was carried out using Olympus Cell-F (version 3.1; Olympus Soft Imaging Solutions GmbH: Münster, Germany) imaging software and PaintShop Pro X5 software (version 15.0.0.183; Corel Corporation, Ottawa, Canada). The identification of particular chromosomes were made by comparing the signal pattern of 5S rDNA, 25S rDNA, pSc119.2 and pAs1 probes according previous study (Kwiatek et al. 2013) and similar cytogenetic analysis (Cuadrado and Jouve 1994; Schneider et al. 2003,
2005; Wiśniewska et al. 2013). Single-factor analysis of variance and Tukey's Honest Significant Difference (HSD) test was used to examine the differences of means of chromosome configurations between plants from respective generations and the differences of means of chromosome configurations between plants from $\mathrm{BC}_{2} \mathrm{~F}_{1}$ with comparison to their progeny in $\mathrm{BC}_{2} \mathrm{~F}_{2}$ generation.

\section{PCR amplification of powdery mildew resistance gene marker}

Genomic DNA was extracted from fresh leaves of single plants using GeneMATRIX Plant \& Funghi DNA Purification Kit (EURx Ltd.). Total genomic DNAs of $F_{1}$ to $\mathrm{BC}_{2} \mathrm{~F}_{2}$ hybrids were used as templates for PCR. The reaction was performed in $25 \mu \mathrm{l}$ reaction mixture containing: $1.5 \mu \mathrm{l}$ $50 \mathrm{ng} / \mu \mathrm{l}$ of DNA, $2.5 \mu \mathrm{l} 10 \times$ PCR buffer $(50 \mathrm{mM} \mathrm{KCl}$, $1.5 \mathrm{mM} \mathrm{MgCl}_{2}, 10 \mathrm{mM}$ Tris-HCl, $\mathrm{pH} 8.8,0.1 \%$ Triton $\mathrm{X}-100$ ), 1 ul $2.5 \mathrm{mM}$ dNTPs (Thermo Fisher Scientific, Waltham, MA, USA), 12.5 pmol of each primer (UTV14 forward: CGC CAG CCA ATT ATC TCC ATG A and UTV14 reverse: AGC CAT GCG CGG TGT CAT GTG AA; Cenci et al. 1998) (Sigma), and $16 \mu \mathrm{MQ} \mathrm{H}_{2} \mathrm{O}, 0.5 \mu \mathrm{l}(2 \mathrm{U} / \mu \mathrm{l}) \mathrm{Taq}$ Polymerase (Thermo Fisher Scientific). Amplifications were carried out in LabCycler thermocycler (SensoQuest Biomedizinische Elektronik, Goettingen, Germany). Amplification products were electrophoresed at $5 \mathrm{~V} / \mathrm{cm}$ for about $3 \mathrm{~h}$ in $1.5 \%$ agarose gel (Sigma), stained with ethidium bromide (Sigma), visualized under UV light and photographed (Syngen UV visualiser).

\section{Evaluation of the powdery mildew infection}

During the vegetation period, the level of powdery mildew natural infection was evaluated according to COBORU (Cultivated Varieties National Research Centre) recommendations on a $9^{\circ}$ scale, where 9 is the most favourable state for agriculture (Fig. 1b, c). The means of powdery mildew expression scores in $\mathrm{BC}_{1} \mathrm{~F}_{1}, \mathrm{BC}_{2} \mathrm{~F}_{1}, \mathrm{BC}_{2} \mathrm{~F}_{2}$ hybrids, Ae. variabilis $\times S$. cereale ampiploids and triticale 'Lamberto' were compared each year to the results of PCR amplification of Pm13 marker using ANOVA calculations and Tukey's HSD test.

\section{Results}

\section{Pm13 marker analysis and powdery mildew reaction in parental forms}

The amplification products of $517 \mathrm{bp}$ in size were found in DNA extracts of Ae. longissima (PI 604112), Ae. variabilis and 20 plants of Ae. variabilis $\times S$. cereale, which were used in 


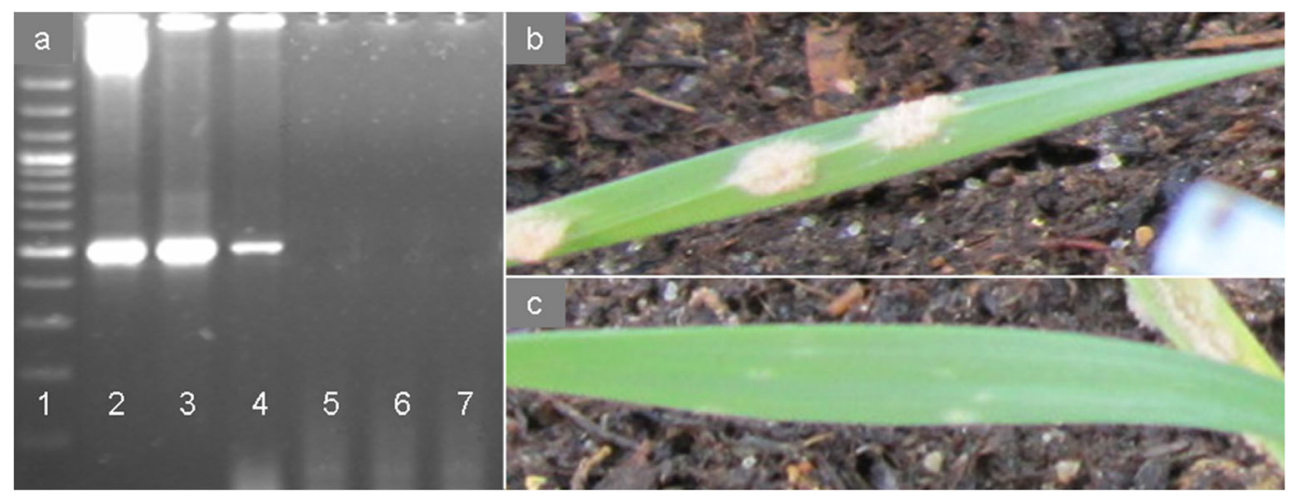

Fig. 1 a Amplification products $(517 \mathrm{bp})$ of PCR with primers specific to Pm 13 gene marker. Lane 1 - 100 bp ladder (GeneRuler, Thermo Fischer Scientific Inc.), lane 2-A. longissima, lane 3-Ae. variabilis, lane 4Ae. variabilis $\times S$. cereale, lane 5-Ae. umbellulata, lane 6-S. cereale

further crosses with triticale. The bands of all samples gave clear and strong fluorescence after separation (Fig. 1a). The marker for $P m 13$ (517 bp) was not identified in rye 'Strzekęcińskie' (used for production of Ae. variabilis $\times$ S. cereale ampihiploids, Wojciechowska and Pudelska 1999) and triticale 'Lamberto.' The powdery mildew expression mean scores in Ae. variabilis were made in three subsequent years of experiments and ranged between 8.05 and 8.25 (Table 3). The observations of the infection symptoms conducted on triticale 'Lamberto' showed much lower tolerance to powdery mildew. The mean scores of infection ranged between 2.85 and 2.95 (Table 3).

\section{Identification of particular mitotic chromosomes of parental forms}

The chromosome composition of Ae. variabilis $\left(\mathrm{U}^{\mathrm{v}} \mathrm{U}^{\mathrm{v}} \mathrm{S}^{\mathrm{v}} \mathrm{S}^{\mathrm{v}}\right)$ and triticale 'Lamberto' (AABBRR), used as parental forms in presented distant crossing were studied (Fig. 2). The analysis were made using 5S rDNA, 25S rDNA (Fig. 2a, d), pSc119.2 and pAs1 probes (Fig. 2b, e) and multicolour GISH with total genomic DNA used as a probe (Fig. 2c, f). Identification of particular chromosomes of A- and B-genome, R-genome, $\mathrm{U}^{\mathrm{u}}$ genome and $\mathrm{S}^{1}$-genome was made basing on previous reports of Cuadrado and Jouve (2002), Schneider et al. (2003, 2005) and Badaeva et al. 1996a, b and 2004, respectively and chromosome arms ratio. The rDNA-FISH experiment on chromosomes of triticale 'Lamberto' $(2 n=6 x=42$ chromosomes, AABBRR) resulted in 12 signals of $5 \mathrm{~S}$ rDNA (on chromosomes $1 \mathrm{~A}, 5 \mathrm{~A}, 1 \mathrm{~B}, 5 \mathrm{~B}, 1 \mathrm{R}$ and $5 \mathrm{R})$ and 6 signals of $25 \mathrm{~S}$ rDNA (on chromosomes: 1B, 6B and 1R; Fig. 2a). By contrast, rDNA-FISH on Ae. variabilis $\left(\mathrm{U}^{\mathrm{v}} \mathrm{U}^{\mathrm{v}} \mathrm{S}^{\mathrm{v}} \mathrm{S}^{\mathrm{v}}\right)$ chromosomes showed 8 signals of $5 \mathrm{~S}$ rDNA in $1 \mathrm{U}^{\mathrm{v}}, 5 \mathrm{U}^{\mathrm{v}}, 1 \mathrm{~S}^{\mathrm{v}}$ and $5 \mathrm{~S}^{\mathrm{v}}$ chromosomes and 8 signals of $25 \mathrm{~S}$ rDNA in $1 \mathrm{U}^{\mathrm{v}}, 5 \mathrm{U}^{\mathrm{v}}, 5 \mathrm{~S}^{\mathrm{v}}$ (weak) and $6 \mathrm{~S}^{\mathrm{v}}$ (weak) chromosomes (Fig. 2d). The same locations of rDNA signals appeared on chromosomes of Ae. variabilis $\times$ $S$. cereale amphiploid. The repetitive sequence FISH (seq-
'Strzękęcińskie,' lane 7 - triticale 'Lamberto'; b leaf of (Ae. variabilis $\times$ $S$. cereale) $\times$ triticale infected by $B$. graminis; $\mathbf{c}$ no symptoms of B. graminis infection

FISH) with pSc 119.2 and pAs1 probes resulted in specific patterns on chromosomes of triticale 'Lamberto' and Ae. variabilis. The chromosomes of A-genome of triticale carried only pAs1 signals, mainly on the distant and pericentromeric regions (Fig. 2b). The most distinguishable chromosome was 7A with strong pAs1 signal on the short arm. The pSc 119.2 and pAs1 signal locations on chromosomes of B-genome of triticale were more diversified and appeared also in interstitial regions. R-genome chromosomes of triticale had strong pSc119.2 sites and weak, dispersed pAs1 signals. The locations of $\mathrm{pSc} 119.2$ sites on $2 \mathrm{R}$ and $3 \mathrm{R}$ chromosomes were similar, but the difference of chromosome arms length allowed to distinguish those two. The chromosomes $\mathrm{U}^{\mathrm{V}}$-genome of Ae. variabilis (Figs. 2e and 3) carried both the pSc119.2 sites and the pAs1 sites. The strongest pSc119.2 signal was observed in the telomeric region of $3 \mathrm{U}^{\mathrm{v}}$ chromosome. The pAs1 sites were located both on distal and interstitial chromosomes. The most characteristic pattern was observed on $6 \mathrm{U}^{\mathrm{v}}$ chromosome. The pSc119.2 and pAs1 probes hybridized also with $\mathrm{S}^{\mathrm{v}}$-genome chromosomes (Fig. 3). The pSc119.2 sites were located on the telomeric regions of chromosomes with an exception of long arm of $5 \mathrm{~S}^{\mathrm{v}}$. The strongest signals were observed on the long arms of $3 \mathrm{~S}^{\mathrm{v}}$ and $7 \mathrm{~S}^{\mathrm{v}}$ chromosomes. The pAs1 sites were mostly dispersed. Distal regions of chromosome $4 \mathrm{~S}^{\mathrm{v}}$ and short arm of chromosome $7 \mathrm{~S}^{\mathrm{v}}$ carried the most visible signals of pAs1.

\section{Evaluation of crossing efficiency}

106 flowers of triticale 'Lamberto' were pollinated by the pollen of Ae. variabilis $\times S$. cereale forms (Table 1). $19 \mathrm{~F}_{1}$ seeds were obtained, that indicates $18 \%$ of crossing efficiency (CE). Six $F_{1}$ plants were germinated and evaluated using GISH analysis. Backcrossing of 68 flowers of $F_{1}$ hybrids with the triticale 'Lamberto' pollen resulted in obtaining of 17 seeds of $\mathrm{BC}_{1} \mathrm{~F}_{1}$ hybrid generation $(\mathrm{CE}=25 \%)$. Five $\mathrm{BC}_{1} \mathrm{~F}_{1}$ plants were chosen on the basis of molecular marker (Pm13) 


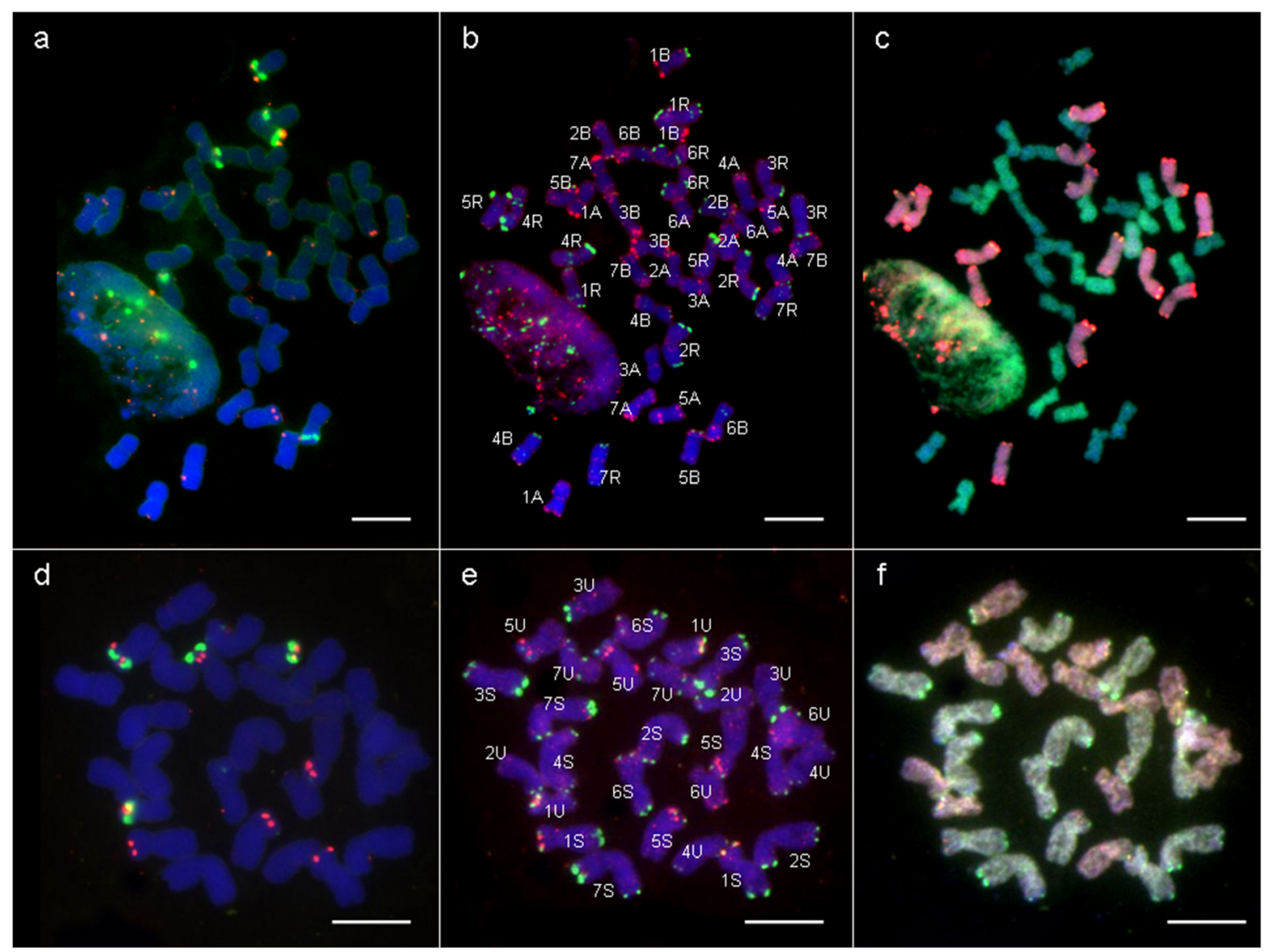

Fig. 2 Fluorescence in situ hybridization (FISH) using 5S and 25S rDNA (a, d); pAs1 and pSc119.2 (b, e) repetitive DNA probes, and genomic in situ hybridization (GISH) on mitotic chromosomes of triticale $(\times$ Triticosecale Wittm.) 'Lamberto' $(\mathbf{a}, \mathbf{b}, \mathbf{c})$ and Ae. variabilis
Eig. (d, e, f). On the GISH images: $\mathbf{c}$ the R-genome is visualized in red, the A-genome in green and the B-genome in blue; $\mathbf{f}$ the $\mathrm{U}^{\mathrm{V}}$-genome is visualized in red and the $\mathrm{S}^{\mathrm{v}}$-genome in green. Scale bars: $10 \mu \mathrm{m}$

\section{Evaluation of introgression of Ae. variabilis chromatin in triticale hybrids}

The correct establishing of the introgression of Ae. variabilis chromatin carrying the resistance to powdery mildew was assured by combining the GISH and FISH methods with molecular marker (Pm13) analysis and the results of infection scoring. The chromosome constitution of six $\mathrm{F}_{1}$ (Ae. variabilis $\times S$. cereale $) \times$ triticale hybrids consist of 28 chromosomes of triticale (14 chromosomes of A- and B-genomes and 14 Rgenome chromosomes), seven $\mathrm{U}^{\mathrm{v}}$-genome chromosomes and seven $\mathrm{S}^{\mathrm{v}}$-genome chromosomes, which were detected by probing with $\mathrm{U}^{\mathrm{u}}$ - and $\mathrm{S}^{\mathrm{l}}$-genomic DNA and blocking with total DNA of triticale (AABBRR) (Table 2, Fig. 4a). FISH experiment with 4 kinds of probes allowed to distinguish chromosomes from each group (group-1 to group-7).

Afterwards, five of 17 plants of the $\mathrm{BC}_{1} \mathrm{~F}_{1}$ generation carried $P m 13$ marker, which was correlated with the infection scores that ranged from 6 to 8 , whereas the another 12 plants were more infected, which was comparable with the infection level of triticale 'Lamberto' (Table 3). In those 5 hybrids (with Pm13 marker) the total number of chromosomes varied from 
Table 2 Cytogenetic analysis of $\mathrm{F}_{1}$ to $\mathrm{BC}_{2} \mathrm{~F}_{2}$ hybrids of triticale 'Lamberto' $\times($ Ae. variabilis $\times$ S. cereale $)$ carrying Ae. variabilis chromatin with Pm13 marker

\begin{tabular}{|c|c|c|c|}
\hline Generation & Number of plants & Chromosome composition & Total number of chromosomes \\
\hline $\mathrm{F}_{1}$ & 6 & $\begin{array}{c}14^{\prime \prime}+1^{\prime} 1 \mathrm{U}^{\mathrm{v}}+1^{\prime} 2 \mathrm{U}^{\mathrm{v}}+1^{\prime} 3 \mathrm{U}^{\mathrm{v}}+1^{\prime} 4 \mathrm{U}^{\mathrm{v}}+1^{\prime} 5 \mathrm{U}^{\mathrm{v}}+1^{\prime} 6 \mathrm{U}^{\mathrm{v}}+1^{\prime} 7 \mathrm{U}^{\mathrm{v}}+1^{\prime} 1 \mathrm{~S}^{\mathrm{v}}+ \\
1^{\prime} 2 \mathrm{~S}^{\mathrm{v}}+1^{\prime} 3 \mathrm{~S}^{\mathrm{v}}+1^{\prime} 4 \mathrm{~S}^{\mathrm{v}}+1^{\prime} 5 \mathrm{~S}^{\mathrm{v}}+1^{\prime} 6 \mathrm{~S}^{\mathrm{v}}+1^{\prime} 7 \mathrm{~S}^{\mathrm{v}}\end{array}$ & 42 \\
\hline \multirow[t]{5}{*}{$\mathrm{BC}_{1} \mathrm{~F}_{1}$} & 1 & $16^{\prime \prime}+1^{\prime} 3 \mathrm{~B}+1^{\prime} 2 \mathrm{U}^{\mathrm{v}}+1^{\prime} 3 \mathrm{U}^{\mathrm{v}}+1^{\prime} 4 \mathrm{U}^{\mathrm{v}}+1^{\prime} 6 \mathrm{U}^{\mathrm{v}}+1^{\prime} 2 \mathrm{~S}^{\mathrm{v}}+1^{\prime} 3 \mathrm{~S}^{\mathrm{v}}+1^{\prime} 4 \mathrm{~S}^{\mathrm{v}}$ & 40 \\
\hline & 1 & $16^{\prime \prime}+1^{\prime} 3 \mathrm{U}^{\mathrm{v}}+1^{\prime} 4 \mathrm{U}^{\mathrm{v}}+1^{\prime} 2 \mathrm{~S}^{\mathrm{v}}+1^{\prime} 3 \mathrm{~S}^{\mathrm{v}}+1^{\prime} 4 \mathrm{~S}^{\mathrm{v}}$ & 37 \\
\hline & 1 & $1^{\prime \prime}+1^{\prime} 2 B+1^{\prime} 2 U^{v}+1^{\prime} 3 U^{v}+1^{\prime} 4 U^{v}+1^{\prime} 2 S^{v}+1^{\prime} 3 S^{v}+1^{\prime} 4 S^{v}$ & 41 \\
\hline & 1 & $17^{\prime \prime}+1^{\prime} 2 U^{v}+1^{\prime} 3 U^{v}+1^{\prime} 4 U^{v}+1^{\prime} 6 U^{v}+1^{\prime} 7 U^{v}+1^{\prime} 2 S^{v}+1^{\prime} 3 S^{v}+1^{\prime} 4 S^{v}+1^{\prime} 7 S^{v}$ & 43 \\
\hline & 1 & $17^{\prime \prime}+1^{\prime} 2 U^{v}+1^{\prime} 3 U^{v}+1^{\prime} 4 U^{v}+1^{\prime} 6 U^{v}+1^{\prime} 2 S^{v}+1^{\prime} 3 S^{v}+1^{v} 4 S^{v}+1^{\prime} 7 S^{v}$ & 42 \\
\hline \multirow[t]{5}{*}{$\mathrm{BC}_{2} \mathrm{~F}_{1}$} & 3 & $20^{\prime \prime}+1^{\prime} 3 \mathrm{~S}^{\mathrm{v}} / 3 \mathrm{~B}$ & 41 \\
\hline & 4 & $21^{\prime \prime}+1^{\prime} 3 \mathrm{~S}^{\prime}$ & 43 \\
\hline & 6 & $20^{\prime \prime}+1 " 3 \mathrm{~S}^{\mathrm{v}} / 3 \mathrm{~B}$ & 42 \\
\hline & 1 & $20^{\prime \prime}+1^{\prime} 3 \mathrm{~S}^{\mathrm{v}} / 3 \mathrm{~B}+1^{\prime} 2 \mathrm{~S}^{\mathrm{v}}$ & 43 \\
\hline & 1 & $20^{\prime \prime}+1^{\prime} 2 \mathrm{~B}+1^{\prime \prime} 3 \mathrm{~S}^{\mathrm{v}} / 3 \mathrm{~B}+1^{\prime} 2 \mathrm{~S}^{\mathrm{v}}$ & 44 \\
\hline \multirow[t]{3}{*}{$\mathrm{BC}_{2} \mathrm{~F}_{2}$} & 9 & $21^{\prime \prime}+1^{\prime} 3 \mathrm{~S}^{\mathrm{v}}$ & 43 \\
\hline & 10 & $20^{\prime \prime}+1^{\prime \prime} 3 \mathrm{~S}^{\mathrm{v}} / 3 \mathrm{~B}$ & 42 \\
\hline & 7 & $21^{\prime \prime}+1^{\prime \prime} 3 \mathrm{~S}^{\mathrm{v}}$ & 44 \\
\hline
\end{tabular}

$\mathrm{xx}^{\prime \prime}$ - number of pairs of triticale chromosomes, 1"xy- one pair of y-genome chromosomes of group-x; 1'xy- a singular group-x chromosome of ygenome; 1"xy/xz- substitution pair of chromosomes. The nomenclature and abbreviation of the genetic stocks of hybrids were described according Raupp et al. 1995 (http://wheat.pw.usda.gov/ggpages/nomenclature.html)

37 to 43 (Table 2). The number of $\mathrm{U}^{\mathrm{v}}$-genome chromosomes was between 2 and 5 , the number of $\mathrm{S}^{\mathrm{v}}$ chromosomes was 34 , the number of R-genome chromosomes was 14 in each plant and the A and B-genome chromosomes number varied from 18 to 21 (Fig. 4b). The 12 other plants, without Pml3 marker, had large number of intergeneric translocations. The GISH analysis showed the chromosomes of A- and B-genome with the translocations of S-genome chromosome segments (Fig. 4c). Selected five $\mathrm{BC}_{1} \mathrm{~F}_{1}$ hybrids (with Pml3 marker) were backcrossed with triticale pollen. The molecular analysis showed that the 3 of $5 \mathrm{BC}_{1} \mathrm{~F}_{1}$ plants reproduced 15 descendants $\left(\mathrm{BC}_{2} \mathrm{~F}_{1}\right)$ with the Pm13 marker (Table 1). The infection scores of those group of hybrids were significantly different in comparison with hybrids without Pm13 marker and triticale 'Lamberto.'

The $\mathrm{U}^{\mathrm{v}}$-genome chromosomes were not identified in all of 15 plants of $\mathrm{BC}_{2} \mathrm{~F}_{1}$ generation, but 1 to 3 chromosomes of $\mathrm{S}^{\mathrm{v}}$ genome appeared in those plants (Fig. 4d). FISH analysis showed that 3 plants carried 41 chromosomes with one chromosome $3 \mathrm{~S}^{\mathrm{v}}$ and the lack of $3 \mathrm{~B}$ chromosome pair. Another 4 plants possessed additional chromosome $3 \mathrm{~S}^{\mathrm{v}}$. The 6 other plants carried substitution pair of $3 \mathrm{~S}^{\mathrm{v}} / 3 \mathrm{~B}$ chromosomes. Moreover, one of $\mathrm{BC}_{2} \mathrm{~F}_{1}$ hybrids had a substitution pair of $3 \mathrm{~S}^{\mathrm{v}} / 3 \mathrm{~B}$ chromosomes and one additional chromosome $2 \mathrm{~S}^{\mathrm{v}}$. The other singular plant carried: a substitution pair of $3 \mathrm{~S}^{\mathrm{v}} /$ $3 \mathrm{~B}$ chromosomes, an one additional $2 \mathrm{~S}^{\mathrm{v}}$ chromosome and one chromosome 2B (Table 2).

In the $\mathrm{BC}_{2} \mathrm{~F}_{2}$ generation the $\mathrm{S}^{\mathrm{v}}$-genome chromosomes were eliminated in 24 plants, however in 26 hybrids $1-2$ chromosomes of $\mathrm{S}^{\mathrm{v}}$-genome were identified and the range of triticale chromosomes was the same as in the previous generation. FISH experiments allowed to distinguish 9 plants with one, additional chromosome $3 \mathrm{~S}^{\mathrm{v}}, 10$ plants with a substitution pair of $3 \mathrm{~S}^{\mathrm{v}} / 3 \mathrm{~B}$ chromosomes and 7 plants with an additional pair of $3 \mathrm{~S}^{\mathrm{v}}$ chromosomes. $P m 13$ marker was identified only in plants with introgression of Aegilops chromatin, which was correlated with the powdery mildew infection scores (Table 3).

\section{Chromosome pairing behaviour in $\mathrm{BC}_{2} \mathrm{~F}_{1}$ and $\mathrm{BC}_{2} \mathrm{~F}_{2}$ of $($ Ae. variabilis $\times S$. cereale $) \times$ triticale hybrids}

The multicolour GISH allowed to distinguish the $\mathrm{S}^{\mathrm{v}}$-genome chromosomes (green) and the triticale chromosomes (Fig. 5ad). Chromosome configuration means at $\mathrm{MI}$ of meiosis in PMCs were examined in selected hybrid plants of $\mathrm{BC}_{2} \mathrm{~F}_{1}$ with total number of chromosomes amounting 42 , that carried a substitution pair of $3 \mathrm{~S}^{\mathrm{v}} / 3 \mathrm{~B}$ chromosomes (Table 4) and in $\mathrm{BC}_{2} \mathrm{~F}_{2}$ hybrids divided in two groups. First group consisted of plants with 42 chromosomes, having a substitution pair of $3 \mathrm{~S}^{\mathrm{v}} / 3 \mathrm{~B}$ chromosomes (Table 5 ), while second group associated the plants with 43 chromosomes having an additional $3 \mathrm{~S}^{\mathrm{v}}$ chromosome (Table 6).

The variance analysis of the chromosome configurations in $\mathrm{BC}_{2} \mathrm{~F}_{1}$ plants with 42 chromosomes, that carried a substitution pair of $3 \mathrm{~S}^{\mathrm{v}} / 3 \mathrm{~B}$ chromosomes showed that the differences between the means of chromosome configurations were not significant (Table 4). The mean of total number of bivalents were 18.02. Bivalents ranged from 9 to 20 per cell. The mean of rod bivalents was nearly two times higher than the mean of ring 
Fig. 4 Genomic in situ hybridization (GISH) on mitotic chromosomes of (Ae. variabilis $\times$ $S$. cereale) $\times$ triticale 'Lamberto' hybrids. On the GISH images, the R-genome is visualized in blue, the A-genome and the B-genome in grey; the $\mathrm{U}^{\mathrm{v}}$-genome is visualized in red and the $\mathrm{S}^{\mathrm{v}}$ genome in green. $\mathbf{a} \mathrm{F}_{1}$ hybrid with 14 chromosomes of Ae. variabilis (7 chromosomes of $\mathrm{U}^{\mathrm{v}}$-genome and 7 chromosomes of $\mathrm{S}^{\mathrm{v}}$ genome). b $\mathrm{BC}_{1} \mathrm{~F}_{1}$ hybrid with 7 chromosomes of Ae. variabilis (4 chromosomes of $\mathrm{U}^{\mathrm{v}}$-genome and 3 chromosomes of $\mathrm{S}^{\mathrm{v}}$-genome). $\mathrm{c}$ $\mathrm{BC}_{1} \mathrm{~F}_{1}$ hybrid with 2

chromosomes from $\mathrm{U}^{\mathrm{v}}$-genome of Ae. variabilis and 21

chromosomes of triticale with introgression of $\mathrm{S}^{\mathrm{v}}$-genome chromatin. $\mathbf{d ~} \mathrm{BC}_{2} \mathrm{~F}_{1}$ hybrid with 3 chromosomes from of $\mathrm{S}^{\mathrm{v}}$-genome of Ae. variabilis. Scale bars: $10 \mu \mathrm{m}$
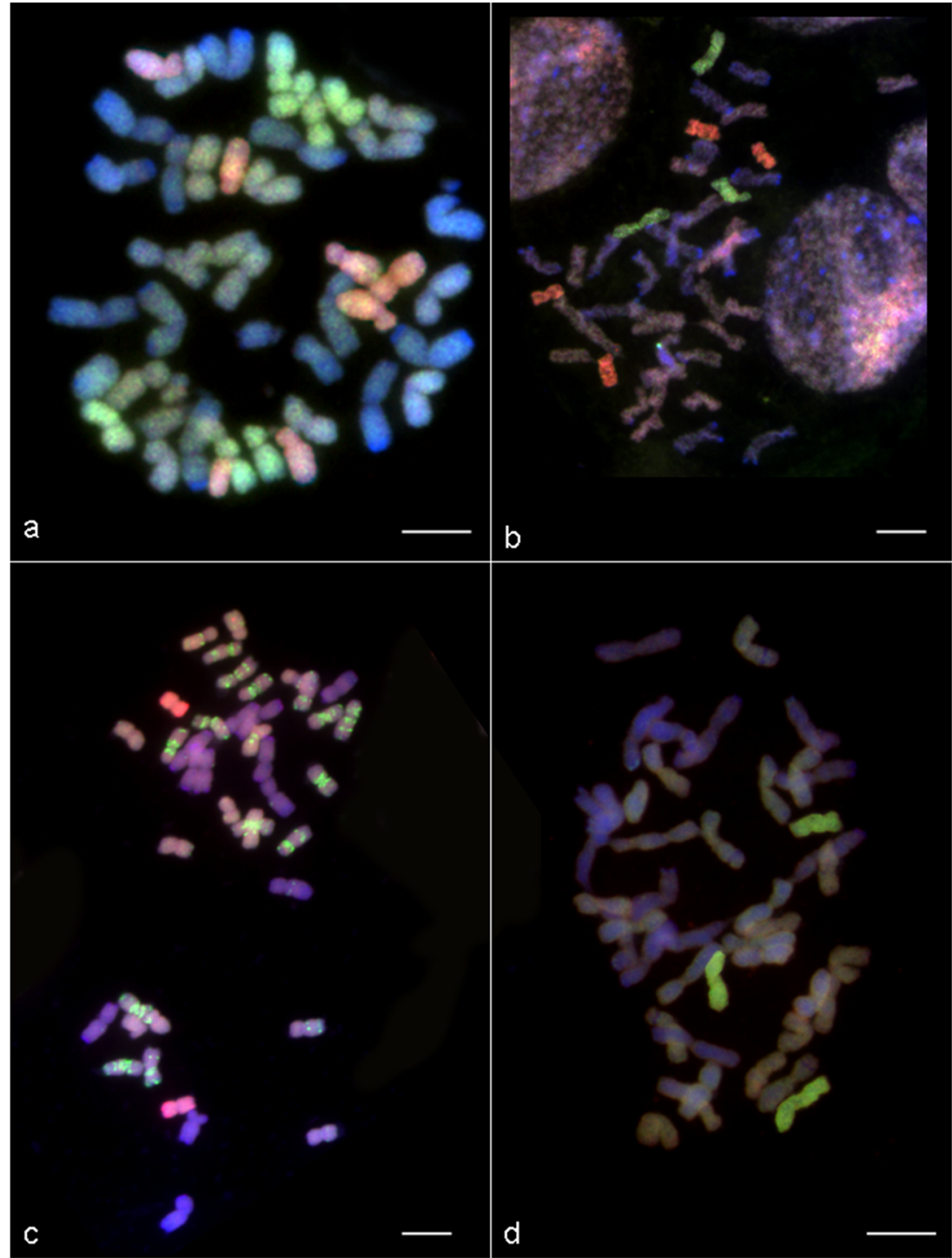

bivalents $(12.22 ; 5.80$; respectively). Similarly, the mean of rod bivalents of A-, B- and R-genome was considerably higher than ring bivalents of those genomes. Considering the $\mathrm{S}^{\mathrm{v}}$-genome bivalents, the mean number of $\mathrm{S}^{\mathrm{v}} / \mathrm{S}^{\mathrm{v}}$ rod bivalents and $\mathrm{S}^{\mathrm{v}} / \mathrm{S}^{\mathrm{v}}$ ring bivalents was almost equal $(0.30$ and 0.38 , respectively). The mean of $\mathrm{S}^{\mathrm{v}}$-genome univalents was 0.72 and the number of univalents ranged between 0 and 2 . The mean chromosome configuration for five analysed plants $\left(2 n=42\right.$ chromosomes) with a substitution pair of $3 \mathrm{~S}^{\mathrm{v}} / 3 \mathrm{~B}$ chromosomes was $5.96 \mathrm{I}+18.02 \mathrm{II}$ (12.22 rod+5.80 ring).

The ANOVA test for $\mathrm{BC}_{2} \mathrm{~F}_{2}$ hybrids with the same chromosome constitution $\left(20^{\prime \prime \prime}+3 \mathrm{~S}^{\mathrm{v} /}\right)$ obtained from different $\mathrm{BC}_{1} \mathrm{~F}_{1}$ plants, carrying a substitution pair of $3 \mathrm{~S}^{\mathrm{v}} / 3 \mathrm{~B}$ chromosomes showed that the differences between means of the chromosome configurations of particular hybrids were not statistically significant. The mean (and the range) of bivalents per $\mathrm{PMC}$ was 18.7 (9-20) and was similar to the results in $\mathrm{BC}_{2} \mathrm{~F}_{1}$ hybrids. The same situation appeared considering the means of rod bivalents, ring bivalents and univalents, where mean chromosome configuration for five analysed $\mathrm{BC}_{2} \mathrm{~F}_{2}$ plants $\left(2 n=42\right.$ chromosomes) with a substitution pair of $3 \mathrm{~S}^{\mathrm{v}} / 3 \mathrm{~B}$ chromosomes was $4.60 \mathrm{I}+18.70 \mathrm{II}$ (12.56 rod+6.14 ring). The mean of rod and ring $\mathrm{S}^{\mathrm{v}}$-genome bivalents was approximate ( 0.22 and 0.46 ; respectively). The comparison of ANOVA results of chromosome configuration between $\mathrm{BC}_{2} \mathrm{~F}_{1}$ and respective $\mathrm{BC}_{2} \mathrm{~F}_{2}$ progeny hybrids shows that the differences in means are not significant. Considering the $\mathrm{S}^{\mathrm{v}}$ genome univalents, the mean in $\mathrm{BC}_{2} \mathrm{~F}_{2}$ plants (Table 5) was lower than in $\mathrm{BC}_{2} \mathrm{~F}_{1}$ plants (Table 4). Five of six hybrids of $\mathrm{BC}_{2} \mathrm{~F}_{1}$ (42 chromosomes each), which carried a substitution pair of $3 \mathrm{~S}^{\mathrm{v}} / 3 \mathrm{~B}$ chromosomes were evaluated (Table 2). All of them were the progeny of the most fertile hybrid line no. 4 (Table 1).

Chromosome configuration means at $\mathrm{MI}$ of meiosis in PMCs were also examined in four $\mathrm{BC}_{2} \mathrm{~F}_{2}$ hybrid plants $\left(2 n=43\right.$ chromosomes) carrying additional chromosome $3 \mathrm{~S}^{\mathrm{v}}$. 
The mean chromosome configuration for this group was 4.65 I+19.18 II (9.9 rod+9.28 ring). The ANOVA and Tukey's HSD test showed that the differences of chromosomes configuration means between plants with the same chromosome constitution $\left(21^{\prime \prime \prime}+3 \mathrm{~S}^{\mathrm{v}}\right)$ obtained from different $\mathrm{BC}_{2} \mathrm{~F}_{1}$ plants (4/6 and 4/10) were significant. The differences affected the means of A-genome, B-genome and R-genome rod and ring bivalents and also means of univalents of A- and B-genome (Table 6).

\section{Discussion}

Considering the growing tendency in brakeage of triticale resistance to fungal diseases, especially powdery mildew, and from the other hand, the narrow genetic diversity of triticale could lead to the conclusion that it is necessary to utilize the wild Triticeae relatives to enrich the genetic pool of cultivated triticale. The gene order in Poaceae species is generally conserved (Chantret et al. 2008) and the synteny facilitates comparative genomics analyses in grass families (Abrouk et al. 2010). Therefore, it could be expected that the region of chromosome $3 \mathrm{~S}^{1}$ of $A$. longissima that is responsible for powdery mildew resistance could be collinear with the same region in the chromosome $3 \mathrm{~S}^{\mathrm{v}}$ of Ae. variabilis $(2 n=4 x=28$, $\left.U^{v} U^{v} S^{v} S^{v}\right)$. Nonetheless, there are discrepant reports concerning the powdery mildew resistance of Ae. variabilis. From the one side, Spetsov and Iliev (1991) obtained a disomic addition line $(2 n=44)$ by crossing wheat cv. 'Roussallka' with Ae. variabilis, that manifested a high powdery mildew resistance in seedling and in adult plant stage. From the other side, Cenci et al. (2003) reported that disomic line of wheat cv. 'Chinese Spring' $3 \mathrm{~S}^{\mathrm{v}}(\mathrm{K}-2)$ and the derived ditelosomic $3 \mathrm{~S}^{\mathrm{v}} \mathrm{S}$ (K-2/SvS) addition lines from Ae. variabilis (Yang et al. 1996) were susceptible, with strong powdery mildew symptoms and abundant sporulation. However, the assumption of a possible synteny between the S-genome chromosomes became meaningful, considering the verification of available powdery mildew STS markers made by Stępień et al. (2001), which showed that Pm13 marker was present in Ae. speltoides (accessions 2056, 2067, d10, d42, d50) that also carry S-genome chromosomes. In presented study, the Ae. variabilis and the Ae. variabilis $\times S$. cereale amphiploids carrying $P m 13$ marker manifested a low powdery mildew reaction, confirmed by infection scores made on 20 plants each year of the experiment (Fig. 1c; Table 3). In comparison, triticale 'Lamberto' was much more infected, which was confirmed by Tukey's HSD test (Fig. 1c; Table 3). Moreover, 1402 Polish isolates of B. graminis are reported to be $100 \%$ virulent to triticale 'Lamberto' in three subsequent years of experiment (20082010) carried out by Czembor et al. (2014). Furthermore, the molecular analysis showed the Pm13 marker was not present in triticale 'Lamberto' (Table 3). The Pm13 marker is located 


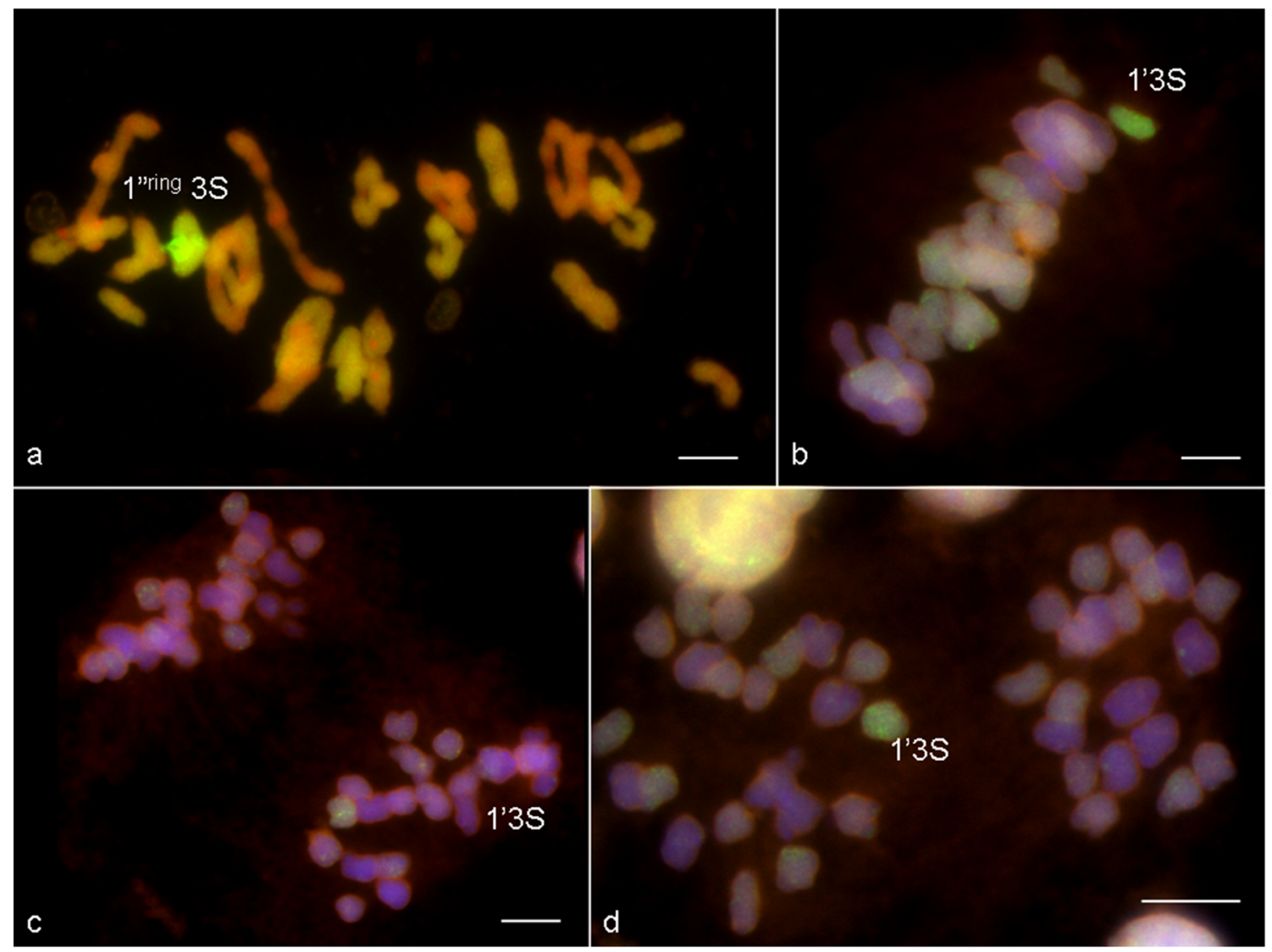

Fig. 5 Chromosome associations at meiosis of pollen mother cells of $\mathrm{BC}_{2} \mathrm{~F}_{2}$ (Ae. variabilis $\times S$. cereale $) \times$ triticale 'Lamberto' hybrids. GISH images created using $\mathrm{S}^{\mathrm{v}}$-genome genomic DNA as a probe (green), with blocking genomic DNA of triticale. Chromosomes were counterstained with propidium iodide (a) or DAPI $(\mathbf{b}, \mathbf{c}, \mathbf{d})$. a One $3 \mathrm{~S}^{\mathrm{v}} /$ $3 \mathrm{~S}^{\mathrm{v}}$ bivalent in $3 \mathrm{~S}^{\mathrm{v}} / 3 \mathrm{~B}$ substitution line $(2 n=42)$ at metaphase I of meiosis. b One $3 \mathrm{~S}^{\mathrm{V}}$ univalent in $3 \mathrm{~S}^{\mathrm{V}}$ addition line $(2 n=43)$ at $\mathbf{b}$ metaphase I, c anaphase I and $\mathbf{d}$ telophase I of meiosis. Scale bars: $10 \mu \mathrm{m}$ on the distal region of the short arm of chromosome $3 \mathrm{~S}^{1}$ (Cenci et al. 2003). In purpose to identify the particular chromosomes of Ae. variabilis, the FISH experiment with repetitive sequences as probes was carried out. The location of $25 \mathrm{~S}$ rDNA and 5S rDNA signals in U- and S-genome chromosomes of Ae variabilis were similar like in the ancestor species, considering chromosomes $1 \mathrm{U}^{\mathrm{u}} 5 \mathrm{U}^{\mathrm{u}}$ and $5 \mathrm{~S}^{1}$ and $6 \mathrm{~S}^{1}$ of Ae. umbellulata and Ae. longissima, respectively (Badaeva et al. 1996b). However, the $25 \mathrm{~S}$ rDNA signals on $1 \mathrm{~S}^{1}, 3 \mathrm{~S}^{1}$ and $6 \mathrm{U}^{\mathrm{u}}$ chromosomes were not present on the homologue chromosomes of Ae. variabilis. There were also some differences in pSc119.2 signals pattern between diploid ancestors (Badaeva et al. 1996a) and Ae. variabilis (Fig. 3). There were no signals in the telomeric regions of long arms of $2 \mathrm{U}^{\mathrm{v}}, 3 \mathrm{U}^{\mathrm{v}}$, $5 \mathrm{U}^{\mathrm{v}}$ and $6 \mathrm{U}^{\mathrm{v}}$ chromosomes. When comparing pAs1 signals on the U-genome chromosomes, small, dispersed signals were observed on $1 \mathrm{U}^{\mathrm{v}}, 3 \mathrm{U}^{\mathrm{v}}$ and $5 \mathrm{U}^{\mathrm{v}}$ chromosomes. Moreover, Badaeva et al. (1996a) did not observed the pAs1 signals on S-genome chromosomes of Ae. longissima, however chromosomes of Ae. variabilis carried weak, scattered landmarks on both arm of each chromosome and strong site on distal region of long arm of $7 \mathrm{~S}^{\mathrm{v}}$ chromosome. The cytogenetic analysis of triticale 'Lamberto' chromosomes revealed also some novel data. The elimination of 25-5.8-18S rDNA was observed in $1 \mathrm{~A}$ chromosome of triticale, comparing to $1 \mathrm{~A}$ of wheat. The rDNA aberrations are probably connected with the changes in ploidy level, which commonly appear in hybrids (Shcherban et al. 2008).

Knowing the cytogenetic markers distribution on the chromosomes of parental forms (Ae. variabilis $\times S$. cereale amphiploids and triticale 'Lamberto'), and the results of Pm13 molecular marker analysis connected with the evaluation of natural infection by $B$. graminis, the study of hybrid generations of $($ Ae. variabilis $\times S$. cereale $) \times$ triticale 'Lamberto' were made. As expected, the $\mathrm{F}_{1}$ hybrids $\left(2 n=6 x=42, \mathrm{U}^{\mathrm{v}} \mathrm{S}^{\mathrm{v}} \mathrm{ABRR}\right)$ carried 7 chromosomes of $\mathrm{U}^{\mathrm{v}}$-, $\mathrm{S}^{\mathrm{v}}$-, A- and B-genome and complete set of 14 chromosomes of R-genome. The chromosome composition of $\mathrm{F}_{1}$ hybrids was anticipated on the basis of related studies, i.e. in the study of Aegilops biuncialis $(2 n=$ $4 x=28$, UUMM $) \times$ wheat $(2 n=6 x=42$, AABBDD $)$ hybridizations (Schneider et al. 2005), the chromosome set of $F_{1}$ hybrids were parallel (ABDUM, $2 n=5 x=35$ ), with only one difference, that in case of $($ Ae. variabilis $\times S$. cereale $) \times$ triticale hybridizations, R-genome chromosomes can pair and behave 


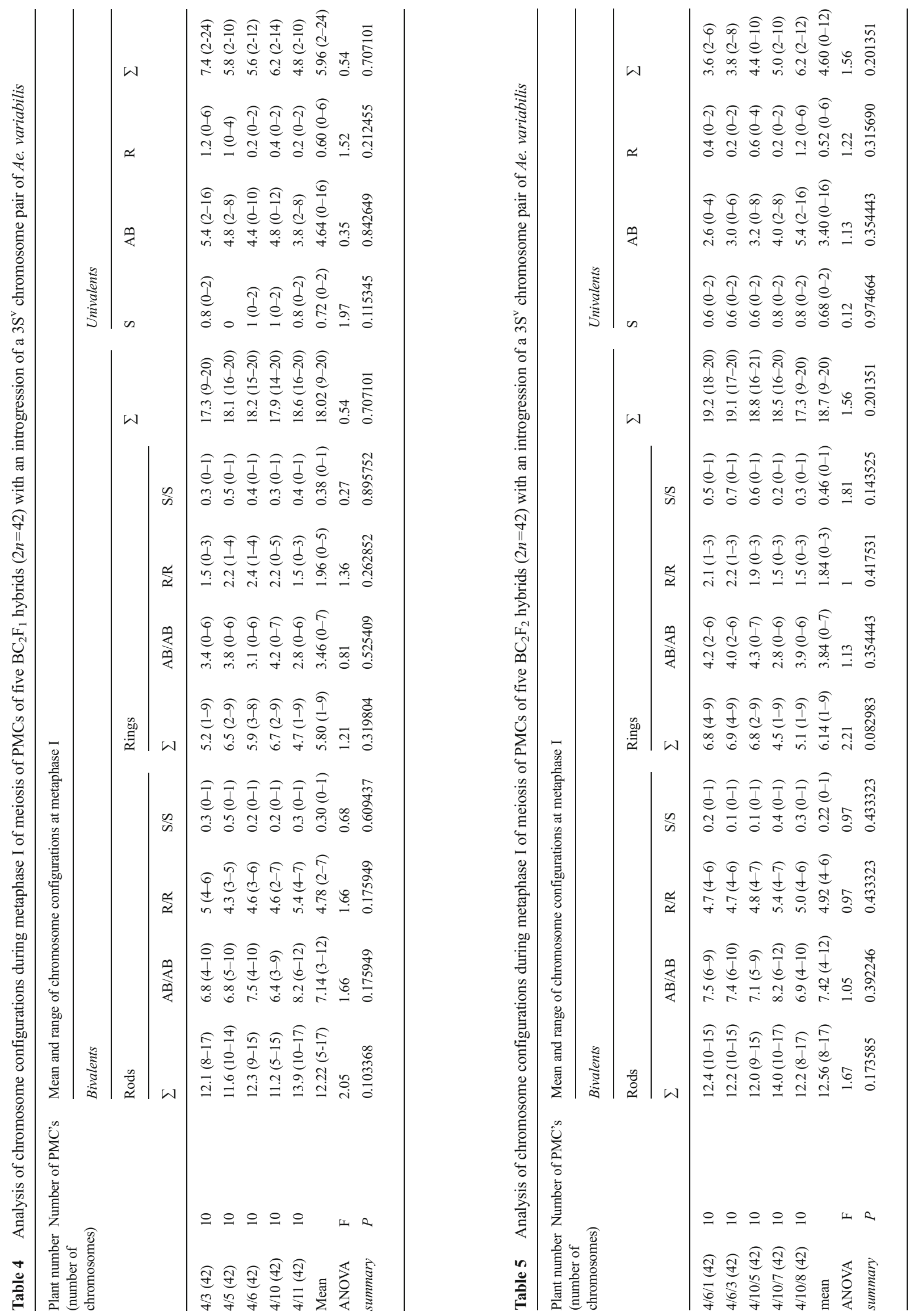




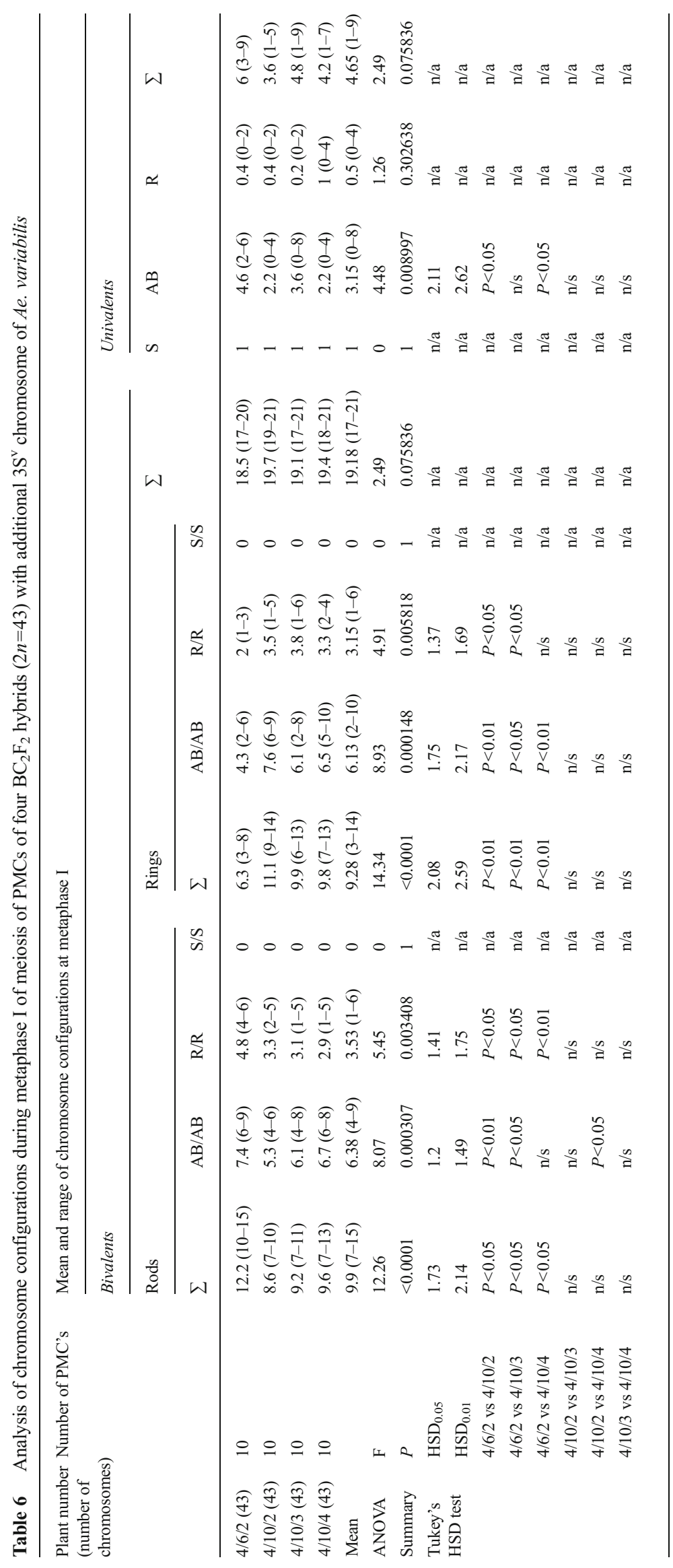


in diploid manner. The crossing of $F_{1}$ hybrids with triticale pollen had an influence on reduction of the Aegilops chromosomes in one group of $\mathrm{BC}_{1} \mathrm{~F}_{1}$ plants and appearing of $\mathrm{S}^{\mathrm{v}} / \mathrm{AB}$ translocations in the latter group of $\mathrm{BC}_{1} \mathrm{~F}_{1}$ plants. Marker analysis showed that plants with Aegilops chromosomes carried also Pm13 marker. Moreover, those plants were much more tolerant for B. graminis infection (Table 3). The further backcrossing of selected $\mathrm{BC}_{1} \mathrm{~F}_{1}$ hybrids with triticale pollen resulted in elimination of Aegilops chromosomes. There was lack of Aegilops chromatin in $9 \mathrm{BC}_{2} \mathrm{~F}_{1}$ plants. On the other hand, FISH/GISH analysis allowed to distinguish chromosome(s) $3 \mathrm{~S}^{\mathrm{v}}$ in each of $15 \mathrm{BC}_{2} \mathrm{~F}_{1}$ plants and in addition, one chromosome $2^{\mathrm{v}}$ in 2 plants, where also Pm13 marker was identified. Moreover, the intensity of the level of powdery mildew infection on those plants was lower, when comparing with triticale 'Lamberto' and hybrids without $P m 13$ marker. Two subsequent backcrosses resulted in the elimination of unneeded Aegilops chromosomes and allow to select the plants with the S-genome chromosomes carrying the resistance. Therefore, the self-fertilization of $\mathrm{BC}_{2} \mathrm{~F}_{1}$ was carried out to maintain the $\mathrm{S}$-genome chromosome in $\mathrm{BC}_{2} \mathrm{~F}_{2}$ hybrids. 26 of 50 hybrids had singular or a pair of $3 \mathrm{~S}^{\mathrm{v}}$ chromosomes, that carried Pm 13 marker and were more tolerant for B. graminis infection. It cannot be omitted, that the HSD test of the means of infection scores of hybrids with Pm13 marker compared with the mean of infection scores of amphiploids (Ae. variabilis $\times S$. cereale) shows the significant differences (Table 3), that points the tolerance for powdery mildew is a little bit lower in hybrids than in amphiploids, however is much higher than in triticale 'Lamberto' and hybrids without Pm13 marker. It can be supposed that triticale 'Lamberto' carry a virulence factors, that have an influence on $P m 13$ gene expression. Notwithstanding, the tolerance for powdery mildew was markedly improved in hybrids with $P m 13$ marker. Afterwards, the genomic in situ hybridization was employed to study the $3 \mathrm{~S}^{\mathrm{v}}$ chromosome(s) behaviour in PMC's of selected $\mathrm{BC}_{2} \mathrm{~F}_{1}$ and $\mathrm{BC}_{2} \mathrm{~F}_{2}$ hybrids of (Ae. variabilis $\times$ S. cereale) $\times$ triticale 'Lamberto.' There were no intergenomic chromosome configurations observed in the plant carrying $2 \mathrm{~S}^{\mathrm{v}}$ and/or $3 \mathrm{~S}^{\mathrm{v}}$ chromosomes, which is opposite to other published studies concerning intergenomic hybridizations between cultivated cereals and Aegilops species. For example, Molnár and Molnár-Láng (2010) reported the intergenomic rod and ring bivalents and trivalent between $2 \mathrm{M}, 3 \mathrm{M}, 3 \mathrm{U}$ and $7 \mathrm{M}$ chromosomes of $\mathrm{Ae}$. biuncialis and wheat (Chinese Spring phlb) chromosomes. It is assumed, that triticale has the same controlling system of homologue chromosome pairing as wheat, that hampers the pairing of the chromosomes from different genomes. In wheat, homoeologous chromosome pairing and consequent recombination is suppressed by the function of the $P h 1$ locus, localized on the long arm of chromosome 5B (Riley and Chapman
1958). The Chinese Spring phlb (CSph1b) mutant genotype (Sears 1977), which lacks the Phl locus, has been successfully used for the introgression of alien genetic material into the wheat genome by the induction of homoeologous pairing (Lukaszewski 2000). From this reason the intergenomic bivalent and trivalent appeared in Molnár and Molnár-Láng (2010) study. Considering presented study, FISH experiments showed that the pair of chromosomes 5B was present in all hybrids of each generation and probably is responsible for diploid-like pairing of chromosomes during meiosis, which was confirmed by ANOVA tests (Tables 4, 5 and 6) that demonstrated no differences in means of chromosome configurations between hybrid plants. However, Tukey's HSD test showed the differences in means of bivalent configurations between $\mathrm{BC}_{2} \mathrm{~F}_{2}$ progeny obtained from $4 / 6$ plant compared with the progeny of $4 / 10$ hybrid (Table 6). It can be supposed that S-genome chromatin has no influence on chromosome pairing of triticale chromosomes. In other words, the way of triticale chromosomes behaviour during first metaphase of meiosis of PMCs seems to be individual regarding to parental form. Furthermore, the way of $3 \mathrm{~S}^{\mathrm{v}}$ chromosome pairing and transmission to next generation is independent, diploid-like.

In conclusion, our study showed that molecular cytogenetics and marker-assisted selection combined with evaluation of powdery mildew infection constitute a useful tool for the resistance breeding. Using these methods we have obtained 26 plants carrying $3 \mathrm{~S}^{\mathrm{v}}$ chromosome(s) with the powdery mildew resistance, which can be used in the triticale breeding programmes. On the other hand, these genetic stocks could be used for sequencing the specific region of $3 \mathrm{~S}^{\mathrm{v}}$ chromosome, responsible for powdery mildew tolerance and for comparative studies with the $P m 13$ gene sequence originated from Ae. longissima.

Acknowledgments We would like gratefully acknowledge the technical assistance of Mrs. Grażyna Cicha and Mrs. Joanna Maszner. We also thank Prof. Barbara Apolinarska for her priceless suggestions and clues. This work was financed by the National Science Centre (DEC-2012/05/ N/NZ9/01563 and DEC-2013/11/D/NZ9/02719).

Author contribution statements M.K. and H.W. initiated the project and designed the study. M.K., M.M. and J.B. performed the research. M.K. wrote the paper.

Conflict of interest The authors declare that they have no conflict of interest.

Open Access This article is distributed under the terms of the Creative Commons Attribution 4.0 International License (http:// creativecommons.org/licenses/by/4.0/), which permits unrestricted use, distribution, and reproduction in any medium, provided you give appropriate credit to the original author(s) and the source, provide a link to the Creative Commons license, and indicate if changes were made. 


\section{References}

Abrouk M, Murat F, Pont C et al (2010) Palaeogenomics of plants: synteny-based modelling of extinct ancestors. Trends Plant Sci 15: 479-487

Ammar K, Mergoum M, Rajaram S (2004) The history and evolution of triticale. In: Mergoum M, Gomez-Macpherson H (eds) Triticale improvement and production. FAO, Rome, FAO Plant Production and Protection Paper 179:1-9

Arseniuk E (1996) Triticale diseases - a review. In: Guedes-Pinto H et al (eds) Triticale: today and tomorrow. Kluwer Acadademic Publisher, The Netherlands, pp 499-525

Badaeva ED, Friebe B, Gill BS (1996a) Genome differentiation in Aegilops. 1. Distribution of highly repetitive DNA sequences on chromosomes of diploid species. Genome 39:293-306

Badaeva ED, Friebe B, Gill BS (1996b) Genome differentiation in Aegilops. 2. Physical mapping of 5S and 18S-26S ribosomal RNA gene families in diploid species. Genome 39:1150-1158

Badaeva ED, Friebe B, Zoshchuk SA, Zelenin AV, Gill BS (1998) Molecular cytogenetic analysis of tetraploid and hexaploid Aegilops crassa. Chromosom Res 6:629-637

Badaeva ED, Amosova AV, Samatadze TE, Zoshchuk SA, Shostak NG, Chikida NN, Zelenin AV, Raupp WJ, Friebe B, Gill BS (2004) Genome differentiation in Aegilops. 4. Evolution of the U-genome cluster. Plant Syst Evol 246:45-76

Cenci A, D’Ovidio R, Tanzarella OA, Ceoloni C, Porceddu E (1998) Identification of molecular markers linked to Pm13, an Aegilops longissima gene conferring resistance to powdery mildew in wheat. Theor Appl Genet 98:448-454

Cenci A, D’Ovidio R, Tanzarella OA, Ceoloni C, Pasquini M, Porceddu E (2003) Genetic analysis of the Aegilops longissima 3S chromosome carrying the Pm13 resistance gene. Euphytica 130:177-183

Ceoloni C, Del Signore G, Pasquini M, Testa A (1988) Transfer of mildew resistance from Triticum longissimum into wheat by induced homoeologous recombination. In: Miller TE, Koebner RMD (eds) Proceedings of the Seventh International Wheat Genetics Symposium. Bath Press, Bath, pp 221-226

Chantret N, Salse J, Sabot F et al (2008) Contrasted microcolinearity and gene evolution within a homoeologous region of wheat and barley species. J Mol Evol 66:138-150

Chen Y, Chełkowski J (1999) Genes for resistance to wheat powdery mildew. J Appl Genet 40:317-334

Coriton O, Barloy D, Huteau V, Lemoine J, Tanguy A-M, Jahier J (2009) Assignment of Aegilops variabilis Eig chromosomes and translocations carrying resistance to nematodes in wheat. Genome 52:338346

Cuadrado A, Jouve N (1994) Mapping and organization of highlyrepeated DNA sequences by means of simultaneous and sequential FISH and C-banding in 6x-triticale. Chromosom Res 2: 331-338

Cuadrado A, Jouve N (2002) Evolutionary trends of different repetitive dna sequences during speciation in the genus Secale. J Hered 93: 339-345

Czembor HJ, Domeradzka O, Czembor JH, Mańkowski DR (2014) Virulence structure of the powdery mildew (Blumeria graminis) population occurring on triticale $(\times$ Triticosecale $)$ in Poland. J Phytopathol 162:499-512

Flor HH (1971) Current status of the gene-for-gene concept. Annu Rev Phytopathol 9:275-296

Gerlach WL, Dyer TA (1980) Sequence organization of the repeating units in the nucleus of wheat which contain $5 \mathrm{~S}$ rRNA genes. Nucleic Acids Res 11:4851-4865

Hasterok R, Dulawa J, Jenkins G, Leggett M, Langdon T (2006) Multisubstrate chromosome preparations for high throughput comparative FISH. BMC Biotechnol 6:1-5
Heslop-Harrison JS (2000) Comparative genome organization in plants: from sequence and markers to chromatin and chromosomes. Plant Cell 12:617-635

Książczyk T, Apolinarska B, Kulak-Książczyk S, Wiśniewska H, Stojałowski S, Łapiński M (2011) Identification of the chromosome complement and the spontaneous $1 \mathrm{R} / 1 \mathrm{~V}$ translocations in allotetraploid Secale cereale $\times$ Dasypyrum villosum hybrids through cytogenetic approaches. J Appl Genet 52:305-311

Kwiatek M, Błaszczyk L, Wiśniewska H, Apolinarska B (2012) Aegilops-Secale amphiploids: chromosome categorisation, pollen viability and identification of fungal disease resistance genes. $\mathrm{J}$ Appl Genet 53:37-40

Kwiatek M, Wiśniewska H, Apolinarska B (2013) Cytogenetic analysis of Aegilops chromosomes, potentially usable in triticale $(\times$ Triticosecale Witt.) breeding. J Appl Genet 54:147-155

Lukaszewski AJ (2000) Manipulation of the 1RS.1BL translocation in wheat by induced homoeologous recombination. Crop Sci 40:216225

Lukaszewski AJ, Kopecký D (2010) The Phl locus from wheat controls meiotic chromosome pairing in autotetraploid rye (Secale cereale L.). Cytogenet Genome Res 129:117-123

Marais GF, McCallum B, Marais AS (2008) Wheat leaf rust resistance gene Lr59 derived from Aegilops peregrine. Plant Breed 127:340 345

Molnár I, Molnár-Láng M (2010) GISH reveals different levels of meiotic pairing with wheat for individual Aegilops biuncialis chromosomes. Biol Plant 54:259-264

Nagaki K, Tsujimoto H, Isono K, Sasakuma T (1995) Molecular characterization ofa tandem repeat, Afa family, and its distribution among Triticeae. Genome 38:479-486

Raupp WJ, Friebe B, Gill BS (1995) Suggested guidelines for the nomenclature and abbreviation of the genetic stocks of wheat and its relatives. Wheat Inf Serv 81:50-55

Riley R, Chapman V (1958) Genetic control of the cytologically diploid behaviour of hexaploid wheat. Nature 182:713-715

Schneider A, Linc G, Molnár-Láng M (2003) Fluorescence in situ hybridization polymorphism using two repetitive DNA clones in different cultivars of wheat. Plant Breed 122:396-400

Schneider A, Linc G, Molnár I, Molnár-Lang M (2005) Molecular cytogenetic characterization of Aegilops biuncialis and its use for the identification of 5 derived wheat - Aegilops biuncialis addition lines. Genome 48:1070-1082

Sears ER (1977) An induced mutant with homeologous pairing in common wheat. Can J Genet Cytol 19:585-593

Shcherban AB, Sergeeva EM, Badaeva ED, Salina EA (2008) Analysis of $5 \mathrm{~S}$ rDNA changes in synthetic allopolyploids Triticum $x$ Aegilops. Mol Biol 42:536-542

Spetsov P, Iliev I (1991) Characterization of a disomic wheat-Ae. variabilis addition line resistant to powdery mildew fungus. Wheat Inf Serv 73:1-4

Spetsov P, Mingeot D, Jacquemin JM, Samardjieva K, Marinova E (1997) Transfer of powdery mildew resistance from Aegilops variabilis into bread wheat. Euphytica 93:49-54

Stępień $€$, Chen Y, Chełkowski J, Kowalczyk K (2001) Powdery mildew resistance genes in wheat: verification of STS markers. J Appl Genet $42: 413-423$

Unfried I, Gruendler P (1990) Nucleotide sequence of the 5.8S and 25S rRNA genes and of the internal transcribed spacers from Arabidopsis thaliana. Nucleic Acids Res 18:4011

Vrána J, Kubalakova M, Simkova H, Cihalikova J, Lysak MA, Dolezel J (2000) Flow sorting of mitotic chromosomes in common wheat (Triticum aestivum L.). Genetics 156:2033-2041

Wiśniewska H, Kwiatek M, Kulak-Książczyk S, Apolinarska B (2013) Introgression of A- and B-genome chromatin into tetraploid rye (Secale cereale L.). J Appl Genet 54:435-440 
Wojciechowska B, Pudelska H (1999) Production, morphology and fertility of the amphiploids Aegilops variabilis $\times$ Secale cereale and Ae. kotschyi $\times$ S. cereale. Cereal Res Commun 27:79-82

Woś H, Metzger RJ, Lukaszewski AJ, Cygankiewicz A (2002) The effect of the D-genome chromosome substitutions and of translocations of chromosome 1D on some quality and agronomic parameters of Winter triticale. In: Proceedings of the 5th International Triticale Symposium, Radzików, Poland, 30 June - 5 July, eds. Arseniuk E, Osinski R, 59-69

Yang Y-C, Tuleen NA, Hart GE (1996) Isolation and identification of Triticum aestivum L. em. Thell. cv. Chinese Spring-T. peregrinum Hackel disomic chromosome addition lines. Theor Appl Genet 92: 591-598
Yu MQ, Jahier J (1992) Origin of $\mathrm{S}^{\mathrm{v}}$ genome of Aegilops variabilis and utilization of the $\mathrm{S}^{\mathrm{v}}$ as analyser of the $\mathrm{S}$ genome of the Aegilops species in the Sitopsis section. Plant Breed 108:290-295

Zhang HB, Dvorák J, Waines JG (1992) Diploid ancestry and evolution of Triticum kotschyi and T. peregrinum examined using variation in repeated nucleotide sequences. Genome 35: 182-191

Zwierzykowski Z, Zwierzykowska E, Taciak M, Jones N, Kosmala A (2008) Krajewski P (2008) Chromosome pairing in allotetraploid hybrids of Festuca pratensis $\times$ Lolium perenne revealed by genomic in situ hybridization (GISH). Chromosom Res 16:575-585 